\title{
ATMOSPHERIC PROCESSES AND THE CHEMISTRY OF SNOW ON THE ROSS ICE SHELF, ANTARCTIGA
}

\author{
By J. A. Warburton and G. O. Linkletter \\ (Energy and Atmospheric Environment Genter, Desert Research Institute, University of \\ Nevada System, Reno, Nevada 89507, U.S.A.)
}

Arstract. Correlations between chemical profiles ( $\mathrm{Na}, \mathrm{K}$ and $\mathrm{Mg}$ ) in three $2 \mathrm{~m}$ deep pits, separated by hundreds of kilometers on the Ross Ice Shelf, suggest that the passage of major storm systems is often recorded as peaks in cationic concentration in the snow-pack on the Ice Shelf. The magnitude of the peaks appears to be a function of both storm intensity and the extent of sea ice adjoining the Ross Ice Shelf. Samples were collected from a network of 21 shallow pits on the Ice Shelf. Although concentration of impurities in the snow varies as a function of distance from the sea on northern portions of the Ross Ice Shelf, a more complex relationship exists in the interior of the Shelf. A distinct chemical zone south of Roosevelt Island may reflect the presence of a "cyclone graveyard". Non-marine cationic ratios in the southern portion of the Ice Shelf suggest the significant influence of a fractionated marine aerosol and the presence of a second, continental aerosol source. Ionic ratios in rime deposited on the Ross Ice Shelf during periods of fog are interpreted as reflecting the production of fog droplets from the chemically-enriched surface microlayer of the ocean. Diffusionally grown snow crystals also have non-marine ratios. In contrast, snowfall associated with peaks in chemical concentration in particular, and the snow-pack on northern portions of the Ross Ice Shelf in general, yield near-marine ionic ratios. This indicates that the chemistry of snow which is near the coast and snow from major storms is dominated by large droplet riming and the associated presence of a high proportion of sea-salt particles.

Résumé. Processus atmosphérique et chimie de la neige dans le Ross Ice Shelf, Antarctique. Les corrélations entre les profils chimiques $(\mathrm{Na}, \mathrm{K}$ et $\mathrm{Mg}$ ) trouvés dans trois forages de $2 \mathrm{~m}$ de profondeur, séparés par des centaines de kilomètres sur le Ross Ice Shelf, font présumer que les passages des principaux systèmes de perturbations sont souvent enregistrés comme des pointes dans la concentration en cations dans les manteaux neigeux sur le Shelf. L'importance de ces pointes semble être une fonction à la fois de l'intensité de la perturbation et de l'importance de la glace de mer attenant au Ross Ice Shelf. Les échantillions étaient rassemblés dans les forages peu profonds dans une grille des 2 I points à travers le Shelf. Bien que la concentration en impuretes dans la neige varie comme une fonction de la distance à la mer dans les parties nord du Ross Ice Shelf, une relation plus complexe s'établit à l'intérieur de la banquise. Une zone chimique distincte au sud de Roosevelt Island peut refléter la présence d'un "cimetière de cyclones". Des teneurs en cations "non marins" dans le sud du Ice Shelf révèlent l'influence significative d'une dispersion de l'aérosol marin et de la présence d'une source secondaire d'aérosol continental. Les rapports ioniques dans le givre déposé sur le Ross Ice Shelf au cours de périodes de brouillard sont interprétés comme le résultat de la production de gouttelettes de brouillard à partir de la microcouche superficielle, chimiquement riche, de l'Océan. Les cristaux de neige crus par diffusion ont nettement des concentrations non marines. Bien que les chutes de neige associées à des maximum de concentration chimique, en particulier et que les manteaux neigeux des régions Nord de l'Ice Shelf, en général, donnent des concentrations ioniques de type marines. Ceci indique que la chimie des neiges subcôtières et celle des neiges des grands épisodes perturbés sont dominés par un fort givrage des gouttelettes et, corrélativement, par la présence d'un forte proportion de particules de sel marin.

Zusammenfassunc. Atmosphärische Vorgänge und der Chemismus des Schnees auf dem Ross Ice Shelf, Antarktika. Zusammenhänge zwischen chemischen Profilen ( $\mathrm{Na}, \mathrm{K}$, und $\mathrm{Mg}$ ) in drei $2 \mathrm{~m}$ tiefen Schächten, die hunderte von Kilometern auf dem Ross Ice Shelf auseinander liegen, lassen darauf schliessen, dass der Durchzug grösserer Zyklonen sich oft durch Maxima der Kationen-Konzentration in der Schneedecke des Schelfeises äussert. Die Grösse der Maxima scheint eine Funktion sowohl der Sturmstärke als auch de angrenzende Meereis Ross Ice Shelf der Ausdehnung des an das zu sein. Die Proben wurden einen Netzwerk von 21 flachen Schächten auf dem Schelfeis entommen. Zwar ändert sich die Konzentration an Verunreinigungen im Schnee in Funktion des Meeresabstandes in den nördlichen Teilen des Ross-Schelfeises, doch herrscht eine kompliziertere Beziehung im Innern des Schelfeises. Eine bestimmte chemische Zone südlich des Roosevelt Island mag das Vorhandensein eines "Zyklonen-Friedhof" andeuten. Nicht-marine Kationenverhältnisse im Südteil des Schelfeises deuten auf den wesentlichen Einfluss eines fraktionierten marinen Aerosols und das Vorhandensein einer zweiten, kontinentalen Aerosolquelle hin. Aus Ionenverhältnissen im Reif, auf dem Ross Ice Shelf abgelagert während Nebelperioden, lässt sich die Produktion von Nebeltröpfchen aus dem chemisch angereicherten Oberflächenfilm des Ozeans annehmen. Schneekristalle, die durch Diffusion gewachsen sind, haben ebenfalls ausgeprägt nicht-marine Verhältnisse. Im Gegensatz dazu ergeben Schneefälle, verbunden mit Maxima der chemischen Konzentration, im besonderen und die Schneedecke auf den nördlichen Teilen des Schelfeises im allgemeinen fast-marine Ionenverhältnisse. Dies deutet darauf hin, dass der Chemismus küstennahen Schnees und der des Schnees aus grösseren Stürmen durch Reifbildung aus grossen Tropfen und - damit verbunden - durch das Vorhandensein eines hohen Anteils an Meeressalzpartikeln bestimmt wird. 


\section{INTRODUCTION}

Snow and ice in glaciers contain particles which have been carried to the surface by falling snow. Additional impurities are added by sedimentation processes. In the high-polar regions, where there is an almost complete absence of melting, the ice sheets contain a long-term record of such depositions and chemical analysis of the snow and ice will reveal the nature of the particles. If the atmospheric processes which control the concentration and composition of these impurities are understood, then it may be possible to use the chemical record to discover certain aspects of the climatic history of the region.

Since the pioneering work of Junge (1960) at Site 2, Greenland, there have been several studies into the chemistry of impurities contained in polar snow and ice. In Antarctica, geographic variations of major and trace elements have been revealed through investigations of samples collected on traverses (e.g. Boutron and others, 1972; Briat and others, 1974). Temporal variations in the chemical content have been studied using ice cores (Langway, 1967; Linkletter, 1970, I973; Ragone and Finelli, 1972; Langway and others, 1974, 1975). Although there is evidence of anthropogenic components to the chemistry, it has been clearly demonstrated that the marine aerosol is the dominant source of impurities in Antarctic snow and ice (Murozumi and others, 1969; Boutron and others, 1972).

So far, little attention has been given to the roles of the fundamental precipitation processes and their influence on the observed chemical variations (except for general considerations of the seasonal distribution of cyclonic storms and their large-scale movement).

During the southern summer of $197 \mathrm{I}-72$, Warburton observed that the relative proportions of accretional and diffusional growth found in ice crystals and snowflakes falling to the surface in Antarctica varied with location. At stations near the coast there was a significantly high proportion of crystals grown by accretion; however, at the South Pole growth was almost entirely by diffusion. These two dominant mechanisms involve different physical processes and operate at very different rates, and so Warburton suggested that their temporal and spatial variations might influence the amounts and composition of impurities incorporated into the polar ice sheets.

The Ross Ice Shelf was chosen as a region devoid of large orographic features where an investigation of the relationships between the chemical composition of the snow and the precipitation forms could be made. This paper presents some results from the first year of this program.

\section{SAMPLING AND LABORATORY PROGEDURES}

Sheets of nylon net were used to collect samples of falling snow during storms, and rime and hoar during periods of supercooled fog at $\mathrm{C}_{7}$ and the Ross Ice Shelf Project (RISP) Base Camp (Fig. I). The nylon nets on which the precipitation was collected, and all the other equipment with which the samples came into contact, were cleaned by a series of leachings in extremely pure solutions of nitric acid. This treatment was followed by several rinses and leachings in doubly-distilled, de-ionized water. All the equipment was then sealed in polyethylene bags for transport to the Antarctic. Samples were taken from the nets with a scoop once a sufficient quantity had accumulated, they were then stored in tightly-sealed polyethylene bags and kept frozen until analysis.

The snow-pack was intensively sampled in pits of $2 \mathrm{~m}$ depth at $\mathrm{C} 7$, RISP Base Camp and Roosevelt Island Camp (RIC), in addition, three or four samples were collected from each of 2 I shallow pits at sites which we visited with RISP glaciologists (Fig. I). After the pits had been excavated, 5-ro cm of snow was scraped from the wall which was to be sampled using a carefully cleaned, long-handled scraper made from "Teflon". The samples were collected by inserting wide-mouthed polyethylene jars (of capacity $500 \mathrm{ml}$ and diameter 


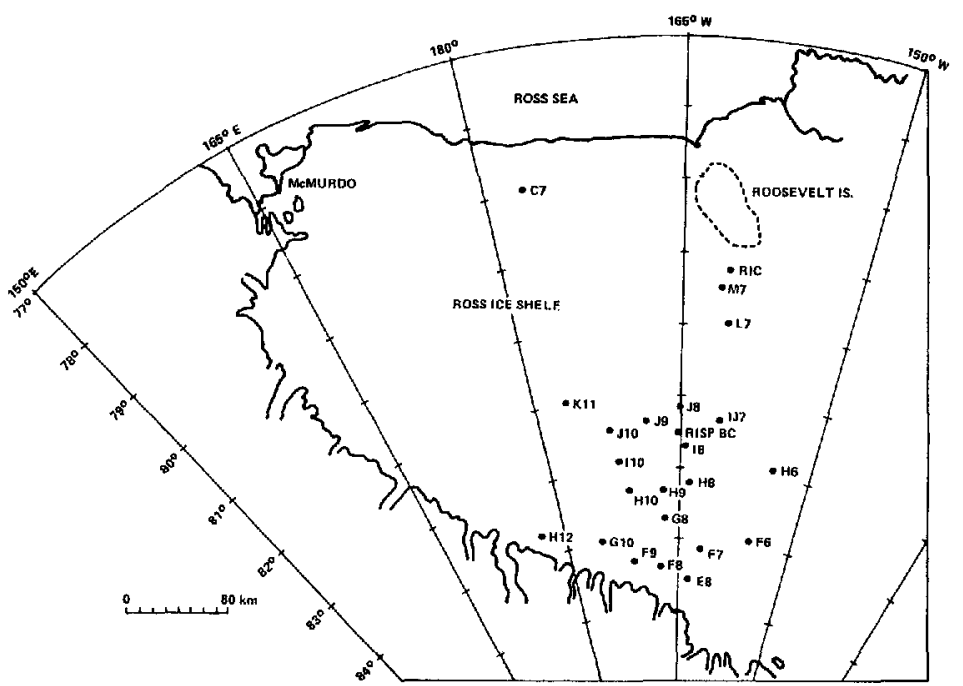

Fig. $1.2 m$ deep pits were intensively sampled at $C_{7}$, RISP BC, and RIC. Three or four snowe samples were collected from the other $2 I$ Rass Ice Shelf locations indicated on the map.

Io $\mathrm{cm}$ ) into the pit wall. The jar screw tops were replaced, and the jars were sealed in polyethylene bags. Each sample covered a depth range of ro cm.

All sample preparation and analyses were conducted in the clean room facility of the Desert Research Institute. Elemental analyses were made using atomic absorption techniques: flame techniques for $\mathrm{Na}$ and $\mathrm{Mg}$ analysis, flameless techniques for $\mathrm{K}$ and low concentrations of $\mathrm{Na}$ and $\mathrm{Mg}$. Matrix standards ( $\mathrm{Na}: \mathrm{Mg}: \mathrm{K}=5: 2: \mathrm{I}$ ) were used to establish reference levels. Each standard and sample analysis was repeated three to five times for each element, depending on the consistency of the machine response. The analytical procedure produced concentration values which have a typical uncertainty of $5-10 \%$.

\section{Results}

Table I shows the concentrations of $\mathrm{Na}, \mathrm{Mg}$, and $\mathrm{K}$, and their ratios in Antarctic snow and ice which have been determined in both this and other work. Whereas most of the concentrations and the ratios found on the Ross Ice Shelf fall within the range of values reported by others, the cationic ratios at the sites on the Shelf farthest from the coast (E, F and G sites) show significant departures from the proportions generally reported at similar distances from the open sea. These results are discussed in greater detail later in the paper.

Table I. Results of chemical analysis of snows from various sites

\section{Location}

Little America ice, $52-84 \mathrm{~m}$ depth Mirny $(45 \mathrm{~km}$ from coast, $820 \mathrm{~m}$ a.s.1.)

"Byrd" Station

Ci pit (sea-level), Ross Ice Shelf

Base Camp pit (sea-level), Ross Ice Shelf

E, F and G site pits, Ross Ice Shelf

Sea-water

\begin{tabular}{|c|c|c|c|c|c|c|}
\hline \multicolumn{3}{|c|}{ Chemical analysis } & \multicolumn{2}{|c|}{ Ionic ratios } & $s_{N a / K}$ & \\
\hline p.p.b. & p.p.b. & p.p.b. & & & & \\
\hline 325 & 42.0 & 21.0 & 7.7 & 2.0 & $15 \cdot 5$ & Langway and others (1974) \\
\hline $4^{8}$ & 7.1 & 2.I & 6.8 & 3.4 & 22.9 & Boutron and others (1972) \\
\hline $3 I$ & 4.0 & I. 5 & 7.8 & 2.7 & 20.7 & $\underset{(1060)}{\text { Murozumi and others }}$ \\
\hline I96 & 22.0 & 8.0 & 8.9 & 2.8 & 24.5 & Warburton and Linkletter \\
\hline $9^{8}$ & 14.0 & 4.0 & 7.0 & $3 \cdot 5$ & 24.5 & Warburton and Linkletter \\
\hline $4^{8}$ & 8.5 & 6.8 & $5 \cdot 6$ & I.2 & 7.1 & Warburton and Linkletter \\
\hline & & & 8.3 & $3 \cdot 3$ & 27.8 & \\
\hline
\end{tabular}




\section{(a) Temporal variations}

Figure 2 shows the variations in concentrations of $\mathrm{Na}, \mathrm{Mg}$, and $\mathrm{K}$ with depth (i.e. time) down to $1.6 \mathrm{~m}$ at the $\mathrm{C}_{7}$, RISP Base Camp, and RIC sites (see Fig. I for locations). At all three sites the concentrations vary markedly with depth. The average maximum-to-minimum ratios for the three sites are $7:$ I for $\mathrm{Na}$, Io : I for $\mathrm{Mg}$, and 9 : I for $\mathrm{K}$; maximum-to-mean ratios average $2.3: \mathrm{I}, 2.6: \mathrm{I}$, and $2.2: \mathrm{I}$ for $\mathrm{Na}, \mathrm{Mg}$, and $\mathrm{K}$ respectively. Except for $\mathrm{Mg}$, the variability is greater at the Base Camp site than at sites nearer the ocean.

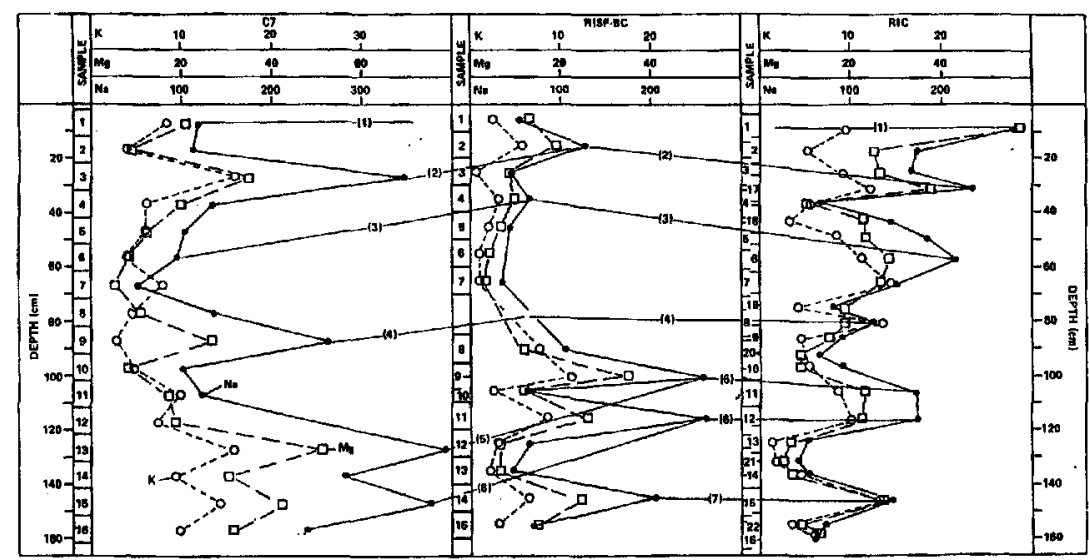

Fig. 2. Temporal variations in $\mathrm{Na}, \mathrm{Mg}$, and $\mathrm{K}$ concentration peaks have been correlated both on the basis of the pattern and spacing of peaks and of the mean annual snow accumulation at the three sites.

At any one site, the distinctive high-concentration peaks generally occur at the same depths for the three elements. Also, as was reported in an earlier comparison of the $\mathrm{C}_{7}$ and Base Camp profiles (Warburton and Linkletter, 1977), the ratio of the depths of the welldefined peaks at both sites was $\mathrm{I} .4: \mathrm{I}\left(\mathrm{C}_{7}: \mathrm{BC}\right)$, a figure which is in agreement with the average accumulation ratio for the sites (Crary and others, 1962). Peak number 4 at the $\mathrm{C}_{7}$ site did not have a counterpart at the Base Camp because no sample was collected at the appropriate depth. Peak number 7 at the Base Camp site did not have a $\mathrm{C}_{7}$ counterpart because it would have occurred below the maximum depth sampled at $\mathrm{C}_{7}$.

Although the correlations of concentration maxima at $\mathrm{RIC}$ with those at $\mathrm{G}_{7}$ and Base Camp are not so compelling as those between $\mathrm{C} 7$ and Base Camp, a reasonable correlation does exist. On the basis of the data of Crary and others ( 1962 ), it is expected that the accumulation at RIC will be similar to that at the RISP Base Camp and the proposed correlation of chemical features fits this assumption.

It is important to note that, although the mean values of the ionic ratios at the three sites are on the order of $10 \%$ lower than the sea-water values, the ionic ratios for the concentration peaks are generally quite close to the sea-water ratios. This fact is important in a consideration of the possible origins of these concentration maxima.

\section{(b) Geographic variations}

The geographic distribution of the mean concentrations and the concentration ratios of the $\mathrm{Na}, \mathrm{Mg}$, and $\mathrm{K}$ ions at 24 sites on the south-eastern portion of the Ross Ice Shelf are indicated in Figure 3. The data presented on these maps have been contoured to suggest the general pattern of variation. Data points are often widely spaced, and alternative contour 
schemes are possible. The data for the region south of Roosevelt Island suggests the existence of a zone marked by low concentrations and high ratios of $\mathrm{Na}: \mathrm{K}, \mathrm{Na}: \mathrm{Mg}$, and $\mathrm{Mg}: \mathrm{K}$.

Whereas the pits at $\mathrm{C}_{7}$, Base Camp, and RIC were continuously sampled with depth, the other $2 \mathrm{I}$ shallower pits were not. It is possible that the mean concentrations determined from these two sampling procedures may not be strictly comparable. The ratio of maximum-tominimum concentrations for the shallow pits are, on average, half the value of the ratios found in the three deeper pits, whereas maximum-to-mean concentration values average 0.7 of those of the deeper pits. In spite of these limitations, the clusters of similar values and the
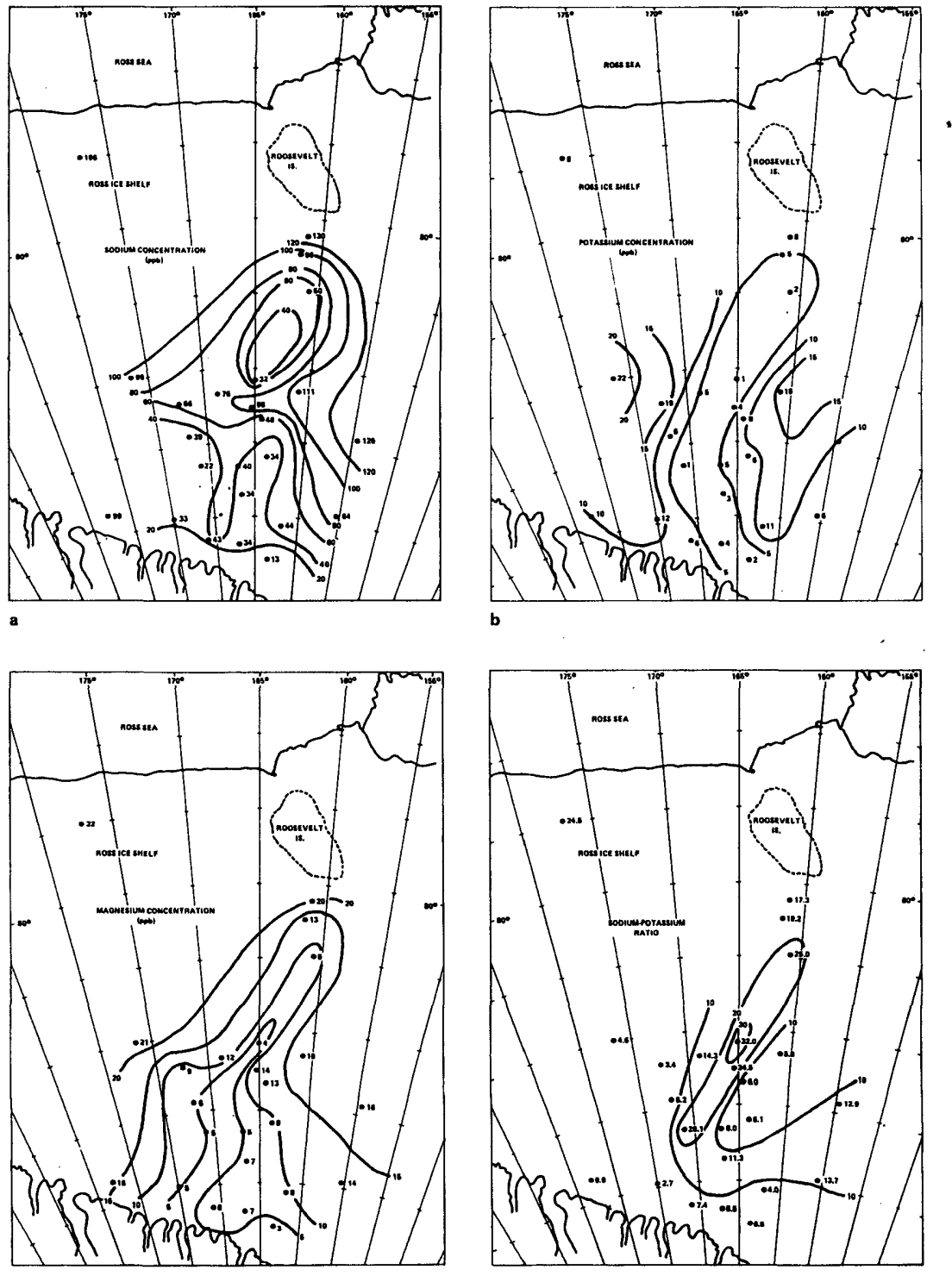

Fig. 3a-d. The geographic variations of $\mathrm{Na}, \mathrm{Mg}$, and $K$ concentrations and their ratios are not a simple function of distance from the sea. Although alternative contouring schemes are possible, all seem to show a feature in the region south of Roosevelt Island. 
sequential spatial variations on the maps indicate that the two data sets can be used together to give a general view of the geographic variability. In no cases do the data from the more intensively sampled sites $\left(\mathrm{C}_{7}\right.$, Base Camp, and $\left.\mathrm{RIC}\right)$ distort the distributional patterns. The two-dimensional diagrams of concentrations and ratios are discussed below in terms of possible causes and origins.
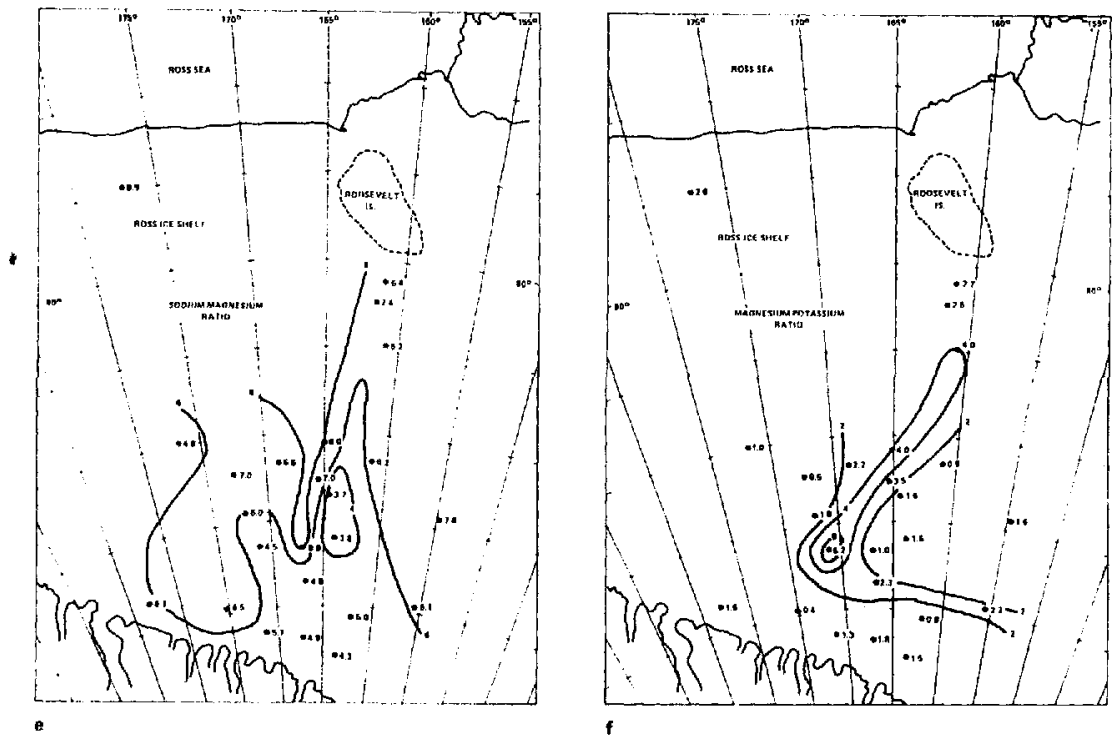

Fig. $3^{3}$ and $f$. The geographic variations of $\mathrm{Na}: M g$ and $\mathrm{Mg}: \mathrm{K}$ ratios.

\section{(c) Chemical variations with precipitation type}

The most common form of precipitation which occurred at $\mathrm{C}_{7}$ and RISP Base Camp during November and December 1974 was a form of diffusional ice deposition on the nylon nets which occurred in supercooled fog conditions. $C_{7}$ experienced fog for $29 \%$ of the time during its two-month occupation. It has been estimated that this diffusional deposition (often in the form of hoar frost) accounts for 5-10\% of the annual accumulation on the Ross Ice Shelf (Linkletter and Warburton, I976). Little snowfall occurred at $\mathrm{C}_{7}$ and only two significant snowfalls were experienced at Base Camp during the observation period.

The mean values for $\mathrm{Na}, \mathrm{Mg}$, and $\mathrm{K}$ concentrations and their ratios in diffusional growth are listed in Table II together with the mean values for the total accumulated snow from the pits at the same sites. The relationship of the elemental concentrations in the diffusional depositions to those of the pit snows differ at the two camps. However, the cationic ratios in

Table II. Results of chemigal analysis of snows from $\mathrm{C}_{7}$ and Base Gamp

G7 site (7o km from edge of Ross Ice Shelf)

Average values in pits

Average values in diffusional fog deposition

Base Camp site ( $45^{\circ} \mathrm{km}$ from edge of Ross Ice Shelf)

Average values in pits

Average values in diffusional fog deposition

Predominantly diffusional growth snowfall

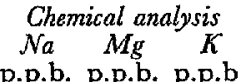

p.p.b. p.p.b. p.p.b.

$\begin{array}{rrrrrl}196 & 22 & 8 & 8.9 & 2.8 & 24.5 \\ 237 & 3^{6} & 17 & 6.6 & 2.1 & 13.9 \\ & & & & & \\ 98 & 14 & 4 & 7.0 & 3.5 & 24.5 \\ 47 & 11 & 4 & 4.3 & 2.8 & 11.8 \\ 54 & 14 & 12 & 3.9 & 1.2 & 4.5\end{array}$


the diffusional-growth ice at both sites are consistently lower than the coastal water values found in the pits. Also listed in Table II are concentrations and ratios for samples collected during a snowfall at the Base Camp site. The cationic ratios in these samples of diffusionally grown snow are also significantly lower than sea-water ratios.

\section{Discussion}

\section{(a) Temporal variations}

A general correlation has been suggested among the chemical records found in the $\mathrm{C}_{7}$, Base Camp, and RIC pits even though the sites are separated by hundreds of kilometers. Although Clausen and Dansgaard (1977) have suggested that the accumulation estimates of Crary and others ( 1962 ) for the southern portion of the Ross Ice Shelf are too large, there is no evidence that the relative variations from place to place are significantly different from those indicated by the earlier work. Because only the Grary and others data cover the area where the pits were located, those data were used here.

The accumulation data indicate that the original correlations, based on the patterns and relative spacings of the peaks, are reasonable in terms of the variations in mean annual accumulation among the three sites. A detailed record of the stratigraphy was made only for the $\mathrm{C}_{7}$ pit and it has not been possible to establish the exact periods of the year in which the concentration peaks occur, solely on the basis of the $\mathrm{C}_{7}$ stratigraphy. However, oxygenisotope data from a site near our Base Camp pit (personal communication from W. Dansgaard) suggest that many of the peaks in cation concentration represent fall and early winter periods. It is clear, however, that the high concentration values are not regularly associated with specific stratigraphic features.

Possible causes of the observed concentration peaks include:

(1) Extended periods of dry fallout of marine aerosols over the Ice Shelf. The stratigraphic record does not support this possibility because high concentrations are not associated with radiation crusts, wind crusts, or other features which would be indicative of a given layer having resided at the surface for an extended period of time.

(2) Periods of storm activity. Three factors make this a possibility: (i) Increased wind velocities associated with storms would increase the proportion of the ocean surface occupied by breaking waves leading to an increased production of sea-salt nuclei (Blanchard and Woodcock, I957). Toba (196r) estimated that an increase in wind velocity from 8.7 to $12.1 \mathrm{~m} / \mathrm{s}$ would increase the number of sea-water droplets of less than $5^{\circ} \mu \mathrm{m}$ diameter entering the atmosphere by a factor of 40 . (ii) During periods of high-velocity winds, the chemically-enriched surface microlayer of the ocean would be broken up and mixed into the deeper water layers. Hence, droplets entering the atmosphere would contain salts of typical sea-water proportions. The ionic ratios in the higher concentration peaks are closer to marine ratios than are those in samples with lower concentrations. (iii) As the maximum water content of the atmosphere is limited by the temperature of the cold Antarctic atmosphere, storm conditions might be expected to produce a proportionally larger increase in sea-salt particles than in liquid-water content for the clouds in which the snow is forming. This could lead to higher salt concentrations in the snowfall occurring during larger storms.

(3) Seasonal (or longer-term) minima in sea-ice extent leading to the closer proximity of large areas of open water directly offshore from the Ross Ice Shelf. By shortening the spacing between the aerosol source and the sampling sites, the observed increases in ionic concentrations could readily be produced (Lodge, 1955; Rossknecht and others, 1973). Recent work by Gordon and Taylor (1975) has shown that the pack ice surrounding the Antarctic continent undergoes large seasonal fluctuations.

(4) A combination of (2) and (3). 
The peaks appear to be the products of large-scale meteorological events occurring over the Ice Shelf, and their chemistry indicates that the aerosols which contribute to the peaks are predominantly of marine origin.

\section{(b) Two-dimensional pariations}

Information into the geographic distribution of the impurities in Antarctic snow which was previously available was based on essentially linear arrays of sampling sites because the samples were collected either during traverses (e.g. Boutron and others, 1972) or at fixed bases. An earlier presentation of chemical data from the Ross Ice Shelf which we have made (Warburton and Linkletter, 1977) also took variations along a line of sampling points, and discussion centered on variations with distance from the sea. Data from the present twodimensional array of sites (Fig. 3) presents a more complex picture.

The broad, flat surface of the Ross Ice Shelf is a region where one might expect to find a rather regular variation of chemistry with distance from the sea. However, Figure 3 makes it clear that the observed distribution is not a simple function of distance from the primary aerosol source. The geographic variations of both concentrations and ratios show a distinct discontinuity to the south of Roosevelt Island. At the moment, the spacing of data points limits our ability to define the overall extent and character of this feature in other than a general way.

The presence of this discontinuity is further suggested by the results of a study into the relationship between mean annual accumulation at sites studied by Glausen and Dansgaard

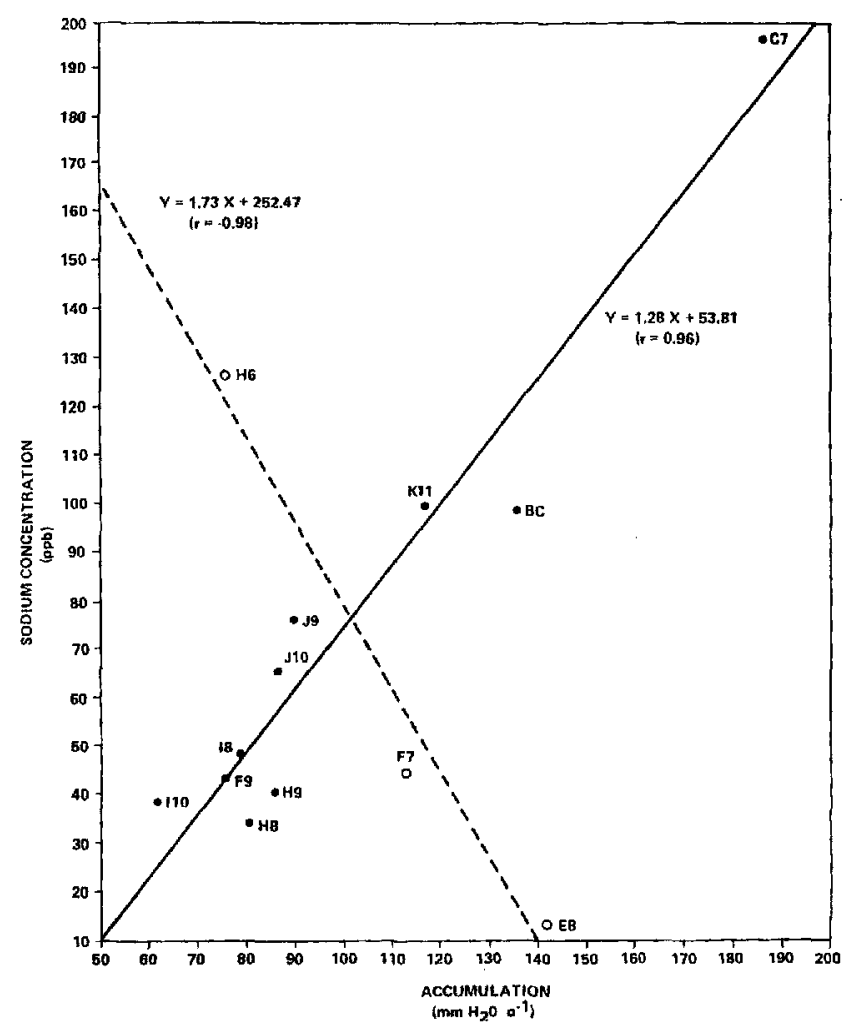

Fig. 4. The presence of two chemistry-accumulation regimes on the eastern portion of the Ross Ice Shelf is suggested by the two distinct relationships indicated. 
(1977) and the sodium content of snow collected at the same sites by the present authors (Fig. 4). Whereas the sodium content increases with accumulation between $\mathrm{F}_{9}$ and $\mathrm{C}_{7}$, along the line between $\mathrm{H} 6$ and $\mathrm{E} 8$ an inverse relationship exists. This result suggests the existence of two zones having different meteorological or accumulation characteristics.

The physiographic and meteorological setting of the Ice Shelf has several features of interest for the present discussion. Both the narrow tongue of higher accumulation (Fig. $5 \mathrm{~b}(\mathrm{I})$ ) and the elongated zone of higher mean annual temperature (Fig. $5 \mathrm{c}$ ( $\mathrm{I})$ ), which cut across the topographic grain of Marie Byrd Land and the polar plateau, appear to reflect the preferred tracking of storm systems across Marie Byrd Land (Fig. 6). The high accumulation zone along the inner edge of the Ice Shelf (Fig. $5^{b}(2)$ ) is caused by the orographic lifting of air masses as they approach the Transantarctic Mountains. This lifting leads to deeper cloud development and to higher precipitation rates and amounts. This effect, extending some distance out onto the Ice Shelf, was observed by the authors on several occasions during the 1974-75 field season. A secondary contribution to this accumulation zone comes from snow transported from the East Antarctic plateau by katabatic winds which probably also produce a slightly warmer zone (Fig. 5c (2)) through the influence of the adiabatically-warmed air which descends through the mountains from the plateau.
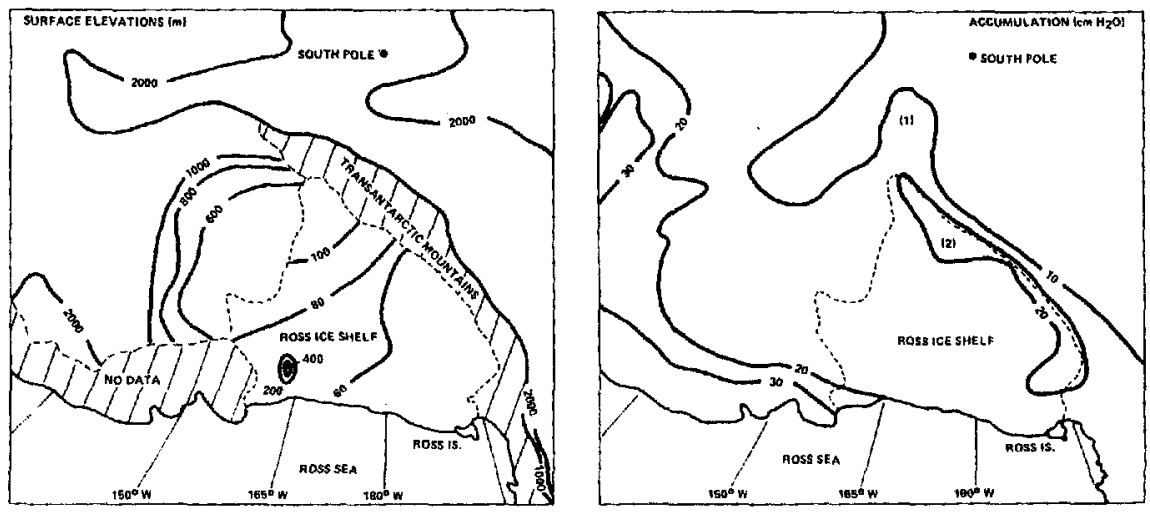

b

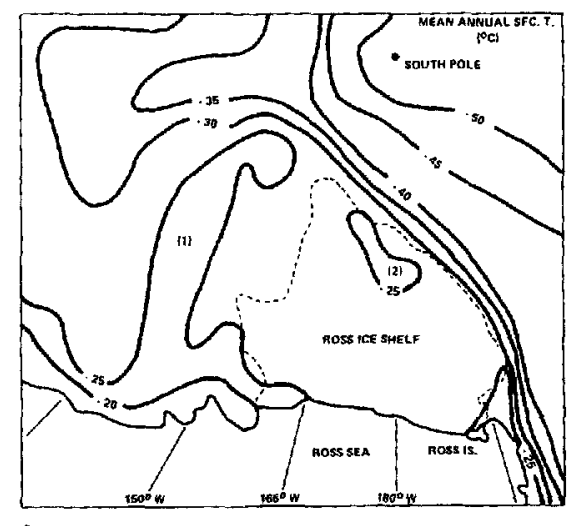

Fig. 5. The physiographic and meteorological setting of the Ross Ice Shelf. $5 b(x)$ and $5_{c}(I)$ are thought to reflect an important storm track with its associated increased incidence of snowfall and advected warmer marine air. The high accumulation zone on the Shelf $(5 b(2))$ is produced by the orographic effect of the Transantartic Mountains. Adiabatically warmed air carried to the Ice Shelf by katabatic winds is probably responsible for $5 c(2)$. (Maps after Bentley and others, 1962.) 


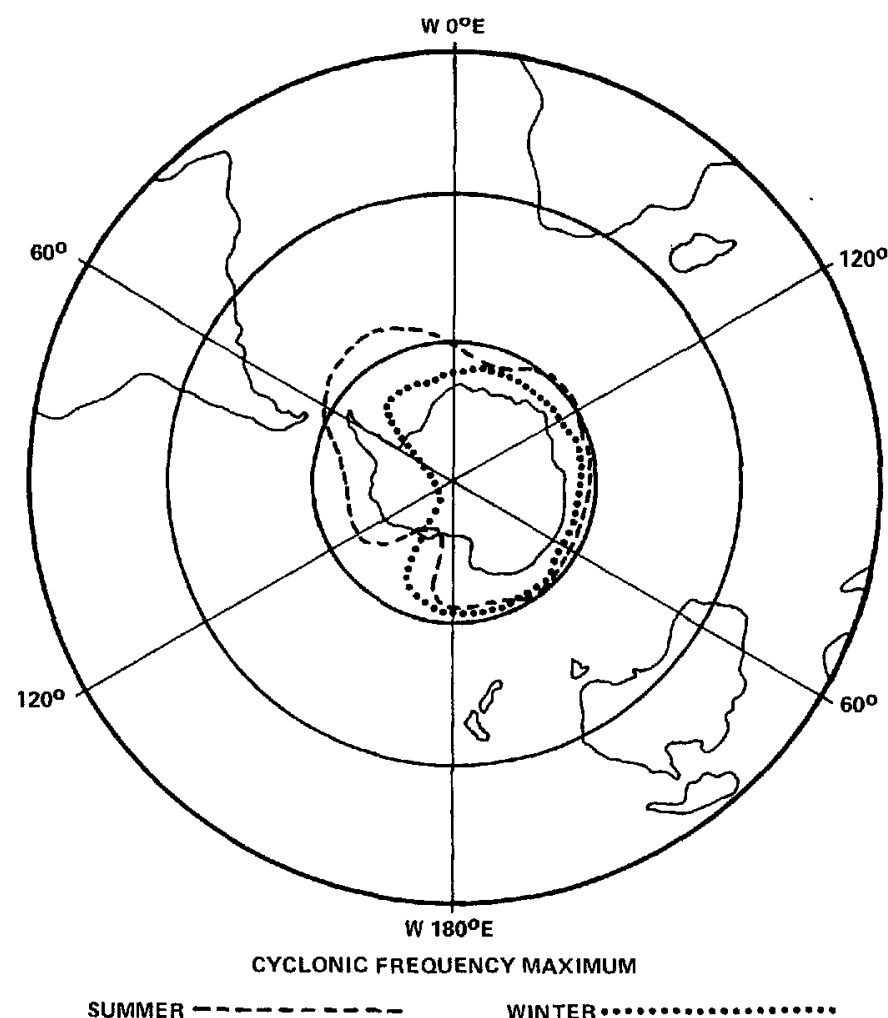

Fig. 6. Cyclonic frequency maxima (Taljaard, 1972) illustrated here, total cloudiness, and the distributions of cyclonic and anticyclonic centers, all indicate that most storms which affect the Ross Ice Shelf initially penetrate the Shelf in the vicinity of Roosevelt Island and the Marie Byrd Land coast.

The distributions of total cloudiness (van Loon, 1972), cyclonic and anticyclonic centers, and cyclonic frequency maxima (Taljaard, 1972) during all seasons show clearly that most storms affecting the Ross Ice Shelf pass near its north-east corner in the vicinity of Roosevelt Island. The winds recorded at Ice Shelf stations and camps reflect this. Some of the storms continue across Marie Byrd Land, but many move along the west slope of Marie Byrd Land (leading, we believe, to the features shown in Figures $5 \mathrm{~b}$ and c), either to penetrate towards the South Pole or to curve back across the interior of the Ross Ice Shelf.

Figure 7 shows the distributions of four parameters on the Ross Ice Shelf as determined by Grary and others (1962). Mean annual temperature, snow hardness, and snow density all have their lowest values in a broad zone south of Roosevelt Island. Although recent work by Clausen and Dansgaard (1977) suggests lower values and a slightly different pattern for accumulation on the southern portion of the Ice Shelf, the overall picture remains basically the same.

The distributions of chemical, meteorological, and glaciological features studied so far may be summarized as follows: Along the lines from $\mathrm{C}_{7}$ to $\mathrm{F}_{9}$, and from $\mathrm{RIC}$ to $\mathrm{L}_{7}$ there is a general decrease in concentration of the cations studied. Although accurate accumulation data are not available for the RIC to $\mathrm{L}_{7}$ sites, there is a positive relationship (correlation coefficient $r=0.96$ ) between accumulation and $\mathrm{Na}$ concentration for the $\mathrm{C}_{7}-\mathrm{F}_{9}$ sequence. It appears that the general decrease in both snow and chemical accumulation found in the region near to the coast does not hold in the interior of the Ice Shelf where chemical variations 

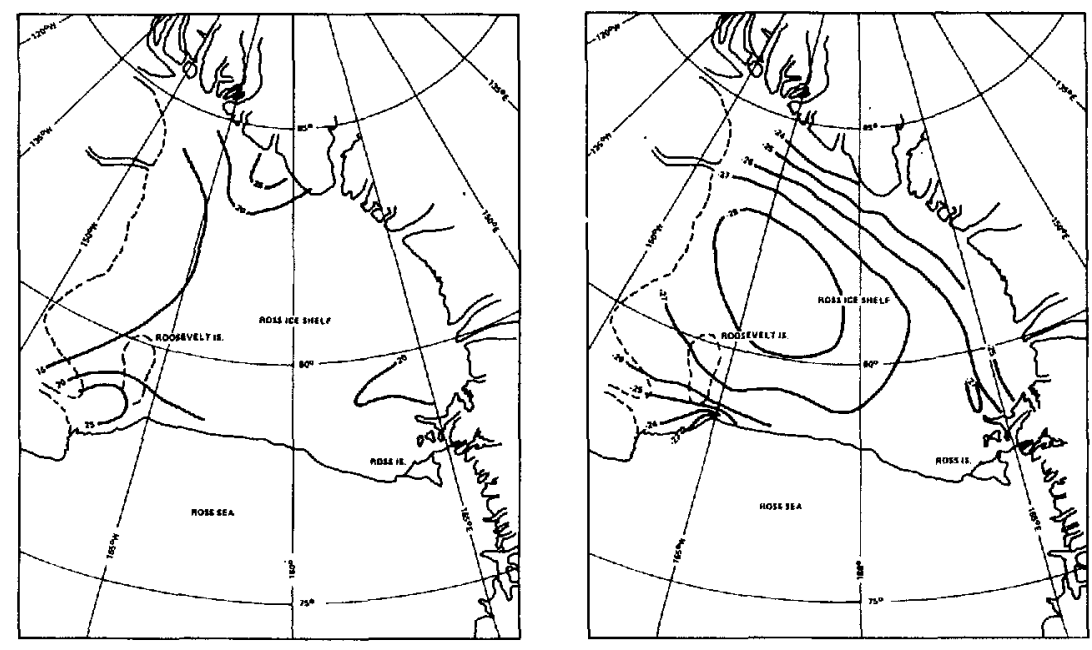

a

b
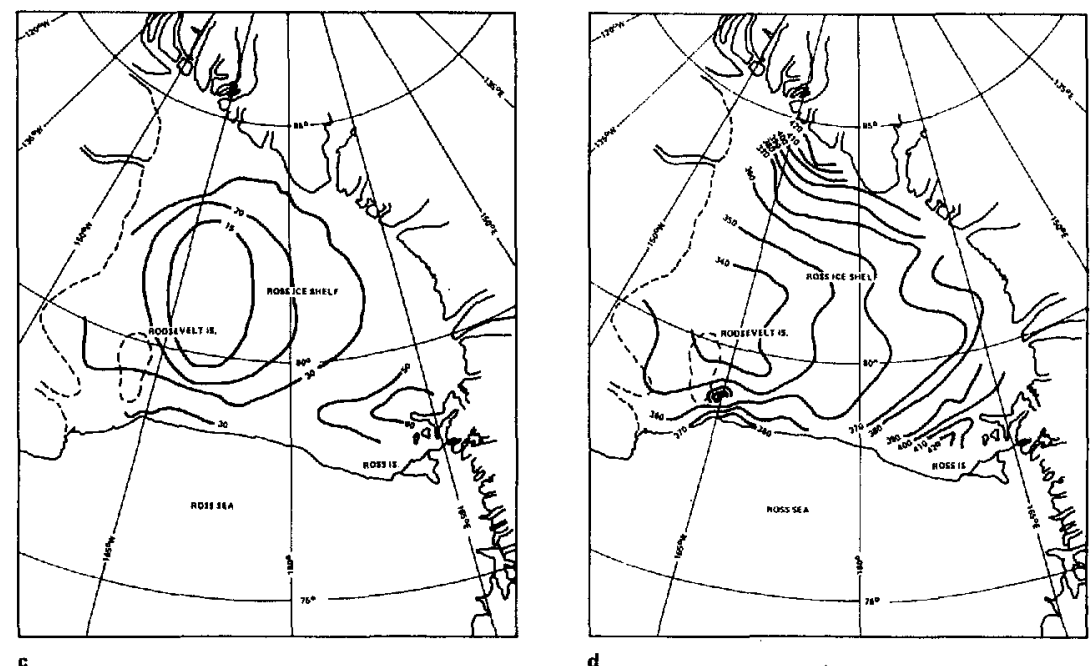

Fig. 7. The variations in (a) average annual accumulation (g/unit area), (b) average annual surface temperature $\left({ }^{\circ} \mathrm{C}\right)$, $(c)$ average snow hardness $(\mathrm{kg})$, and $(\mathrm{d})$ average snow density $\left(\mathrm{Mg}_{\mathrm{m}} \mathrm{m}^{3} \times 1 \mathrm{O}^{3}\right)$ were measured by Crary and others (1962). All parameters have their lowest values in the interior of the Shelf. The patterns south of Roosevelt Island may reflect the movement of storms near and over the Ross Ice Shelf.

are more irregular. However, the positive relationship between accumulation and chemical concentration prevails in at least part of the central region.

We suggest that storm intensity is the dominating and controlling factor from the coast across the center of the Ice Shelf. Warmer, more vigorous storms will not only penetrate further across the Ice Shelf but will contain more liquid water (hence more snowfall) and will have accumulated more marine aerosols while still over open water in the Ross Sea. The positive relationship between accumulation and chemistry suggests that the aerosol content undergoes a proportionally larger increase than does liquid-water content as storm intensity increases, probably due to the limit imposed by temperature on liquid-water content. In 
addition, the chemical data reflect the efficiency with which the precipitation processes clean aerosols from the air and produce a more rapid decrease in chemical concentration than in snowfall, thus accentuating the deviation from a simple I : I relationship. Low enrichment factors for both $\mathrm{Mg}$ and $\mathrm{K}$ (relative to $\mathrm{Na}$ ) at $\mathrm{C}_{7}$ and $\mathrm{RIC}$ indicate that a relatively undiluted, unfractionated marine aerosol predominates near the sea.

A different picture emerges for the southernmost portion of the Ice Shelf. Along the line from $\mathrm{H} 6$ to $\mathrm{E8}$, snow accumulation and $\mathrm{Na}$ concentration (both with significant gradients) are inversely related $(r=0.98)$. The accumulation gradient appears to be much affected by the orographic effect of the Transantarctic Mountains. The chemical gradient is determined by the direction of storm movement through this area, the progressive cleansing of the air by precipitation, and dilution of the aerosol by the rapidly increasing snowfall near the mountains.

The ionic ratios at the southern sites are very different from the coastal ratios to the north. The greatest deviation occurs for the $\mathrm{Na}: \mathrm{K}$ ratio which averages approximately $30 \%$ of the sea-water value along the $\mathrm{E}, \mathrm{F}$, and $\mathrm{G}$ lines of sampling sites. The $\mathrm{Mg}: \mathrm{K}$ averages $45 \%$ and the $\mathrm{Na}: \mathrm{Mg} 65 \%$ of marine ratios at these sites. Although these values may arise only from fractionation of the marine aerosol, the proportionally greater increase in $\mathrm{K}$ concentration required to yield such a marked change in ratio suggests a second aerosol source. Whereas $\mathrm{Na}$ and $\mathrm{Mg}$ are generally considered to be of marine origin, $\mathrm{K}$ can be indicative of a continental aerosol (Langway, 1967). The proximity of exposed rock and glacial deposits in the Transantarctic Mountains suggests a possible local source for an aerosol which is relatively rich in $\mathbf{K}$. In addition, upper tropospheric and stratospheric dust which has traveled long distances enters the Antarctic lower troposphere under subsidence conditions over the interior plateau (Hogan and Nelson, 1975; Hamilton and O'Kelley, I97 I). This aerosol, which could be carried to areas of the Ross Ice Shelf by katabatic winds, would be expected to have lower $\mathrm{Na}: \mathrm{K}$ and $\mathrm{Mg}: \mathrm{K}$ ratios than does sea-water.

The general coincidence of the zone of low chemical concentrations with low values for mean annual temperature, snow density, and snow hardness south of Roosevelt Island are intriguing. Although cationic concentrations are low, their ratios are near to oceanic values. The low concentrations may indicate a tendency for cyclonic disturbances to "die" in this region, as most of the aerosol removal would have already been accomplished. The high incidence of cylonic centers near this area may be attributable to this "graveyard effect" (Taljaard, 1972). The low values for Crary's measured factors may be interpreted in a similar way. The slightly lower temperature may reflect a somewhat reduced advection of marine air across this part of the Ice Shelf whereas the lower density and snow hardness suggest a less windy character in addition to the lower temperature.

\section{(c) Chemical variations with precipitation type}

One aim of the 1974-75 field season was to collect falling snow during storms in order to study the relationship between snow growth mechanisms and chemical composition. This met with only limited success because the incidence of storms was low. Nevertheless, some information which bears on this problem was gathered.

As mentioned above, the most common form of precipitation which occurred at $\mathrm{C}_{7}$ and Base Camp during the 1974-75 field season was riming in supercooled fogs. The fog condition was generally associated with relatively warm air moving across the Ice Shelf in winds of low velocity. The distinctly cellular character of the air masses was indicated by frequent temperature oscillations of up to $5^{\circ} \mathrm{C}$, which occurred at rates as rapid as $0.5^{\circ} \mathrm{C} / \mathrm{min}$. The fogs are associated with the advection of maritime air across the cold snow surface when there are no storms.

The mean concentrations for $\mathrm{Na}, \mathrm{Mg}$, and $\mathrm{K}$ and their ratios in the rime which formed in these fog conditions are listed in Table II. Although the air masses in which the fog formed 
were thought to be of marine origin, the $\mathrm{Na}: \mathrm{K}$ and $\mathrm{Na}: \mathrm{Mg}$ ratios are significantly lower than sea-water values. They are also distinctly different from the average ratios found in the snow taken from the pits at $\mathrm{C} 7$ and Base Camp. A fractionated marine aerosol is suggested as the cause for the $\mathrm{K}$ and $\mathrm{Mg}$ enrichments. Enrichment factors of 2.4 for potassium and $\mathrm{I.2}$ for magnesium are in agreement with Komabayasi ( 1962 ). The small size of the fog droplets (around $20 \mu \mathrm{m}$ diameter) and associated low wind velocities indicate that the enrichment may occur in association with the production of small water droplets from the chemically-enriched surface micro-layer of the ocean. The coastal values for the ionic ratios in the pit samples of snow suggest that the bulk of the accumulation at these sites is from snowfall which contains larger frozen water drops or sea-salt particles introduced into the atmosphere during storm periods when the sea surface is in a more turbulent state.

The apparent importance of the large drop and sea-salt particle contributions to the chemistry of the Ross Ice Shelf, is also supported by the results of chemical analyses of predominantly diffusionally-grown snowfall collected at the Base Camp site. Although only three samples were collected, all showed marked departures from sea-water ratios (Table II).

\section{Conclusions}

The chemical features of snow collected from pits, $2 \mathrm{~m}$ deep, on the Ross Ice Shelf have been correlated between three locations separated by hundreds of kilometers. The peaks in concentration, averaging 7 to ro times the background values, are probably produced when major cyclonic storm systems move, first across the Ross Sea acquiring moisture and marine aerosols, and then over the Ross Ice Shelf where the snow and chemicals are deposited. The magnitude of the concentration peaks may be influenced by the intensity of the storm system and the extent of the sea ice in the Ross Sea.

Although geographic variations in the chemistry of snow on the Ross Ice Shelf are not a simple function of distance from the sea, such a relationship does appear to exist on the northern portions of the Shelf. While the zone of low concentrations immediately south of Roosevelt Island probably reflects the presence of a "cyclone graveyard" in that area, the irregularities in chemistry further south are thought to mark the confluence between a region dominated by storms which have tracked over westernmost Marie Byrd Land and those which have moved directly over the Ice Shelf. The southern portion of the Shelf possesses low concentrations and ionic ratios which are very different from sea-water ratios. Whereas the concentrations reflect the progressive wash-out of aerosols and the dilutional effect of increasing snowfall near the mountains, the ratios suggest a second aerosol source superimposed on a fractionated marine acrosol. The strong katabatic flow from the high plateau onto the Shelf may very well be the dominant low-level transport mechanism for such an aerosol source.

Ionic ratios in rime deposited on the Ross Ice Shelf differ significantly from sea-water ratios. This may be caused by the small droplets in the supercooled fogs which deposit the rime which is produced from the chemically-enriched surface microlayer of the ocean under conditions of low wind velocity. The reason for the snow which is diffusionally grown having ionic ratios which differ markedly from marine values is less clear. The diffusional growth process may produce a fractionation in the atmosphere by the preferential collection of aerosols of certain chemical compositions. In any case, because the ionic ratios on the northern portion of the Shelf are close to those of sea-water, it appears that the accumulation there is dominated by snowfall which has a significant amount of large droplet riming and which contains a higher proportion of sea-salt particles. The increasing importance of diffusional growth processes which is apparent toward the interior of the Ice Shelf (as indicated by the changing ratios, is in agreement with our earlier observations of the increasing proportion of diffusional against accretional growth with distance from the coastline. 


\section{Aaknowledgements}

The authors thank Mr D. A. Trachte and Mr M. S. Owens for their assistance in the field and $\mathrm{Mr}$ A. V. Anderson who performed the chemical analyses. This work was conducted as part of the Ross Ice Shelf Project, under NSF Grant No. OPP73-05843-Aor.

MS. received I February 1977 and in revised form 19 April 1977

\section{REFERENCES}

Bentley, C. R., and others. 1964. Physical characteristics of the Antarctic ice sheet, by C. R. Bentley, R. L. Cameron, C. [B. B.] Bull, K. Kojima and A. J. Gow. Antarctic Map Folio Series (New York, American Geographical Society), Folio 2.

Blanchard, D. C., and Woodcock, A. H. 1957. Bubble formation and modification in the sea and its meteorological significance. Tellus, Vol. 9, No. 2, p. 145-58.

Boutron, G., and others. 1972. Chemistry of polar snows. Estimation of rates of deposition in Antarctica, by $\mathbf{C}$. Boutron, M. Echevin and G. Lorius. Geochimica et Cosmochimica Acta, Vol. 36, No. 9, p. 1029-41.

Briat, M., and others. 1974. Chlorine and sodium content of east Antarctic firn samples, by M. Briat, G. Boutron and C. Lorius. Fournal de Recherches Atmosphériques, Vol. 8, Nos. 3-4, p. 895-901.

Glausen, H. B., and Dansgaard, W. 1977. Less surface accumulation on the Ross Ice Shelf than hithertoassu med. [Union GLodésique et Géphysique Internationale. Association Internationale des Sciences Hydrologiques. Commission des Neiges et Glaces.] Symposium. Isotopes et impuretés dans les neiges et glaces. Actes du colloque de Grenoble, aoutt/septembre 1975 , p. $172-76$. (IAHS-AISH Publication No. 118 .)

Grary, A. P., and others, I962. Glaciological studies of the Ross Ice Shelf, 1957-1960, by A. P. Crary, E. S. Robinson, H. F. Bennett and W. W. Boyd, Jr. IGY Glaciological Report Series (New York), No. 6.

Gordon, A. L., and Taylor, H. W. 1975. Seasonal change of Antarctic sea ice cover. Science, Vol. 187, No. 4174, p. $346-47$.

Hamilton, W. L., and $\mathrm{O}^{\prime} \mathrm{Kelley}$, M. E. 1971. Investigation of particulate matter in Antarctic firn. (In. Grary, A. P., ed. Antarctic snow and ice studies II. Washington, D.C., American Geophysical Union, p. 355-62. (Antarctic Research Series, Vol. 16.))

Hogan, A. W., and Nelson, D. 1975. Aerosol observations over the ice caps. Antarctic Journal of the United States, Vol. to, No. 6, p. 310-12.

Junge, C. E. 1960. Sulfur in the atmosphere. Journal of Geophysical Research, Vol. 65, No. 1, p. 227-37.

Komabayasi, M. I 962 . Enrichment of inorganic ions with increasing atomic weight in aerosol, rainwater and snow in comparison with sea water. Fournal of the Meteorological Society of Japan, Vol. 40, No. 1, p. $25-38$.

Langway, C. C., jr. 1967. Stratigraphic analysis of a deep ice core from Greenland. U.S. Cold Regions Research and Engineering Laboratory. Research Report 77.

Langway, G. C., jr., and others. 1974. Chemical profile of the Ross Ice Shelf at Little America V, Antarctica, by G. C. Langway, Jr., M. M. Herron and J. H. Cragin. U.S. Cold Regions Research and Engineering Laboratory. Research Report $3 \mathbf{1 6 .}$

Langway, G. C., jr., and others. 1975. Seasonal variations of chemical constituents in annual layers of Greenland deep ice deposits, by G. G. Langway, Jr., J. H. Gragin, G. A. Klouda and M. M. Herron. U.S. Cold Regions Research and Engineering Laboratory. Research Report 347.

Linkletter, G. O. 1970 . The use of cationic ratios in determining annual stratigraphic layers in polar ice. [Union Géodésique et Géophysique Internationale. Association Internationale d'Hydrologie Scientifique.] [International Council of Scientific Unions. Scientific Committee on Antarctic Research. International Association of Scientific Hydrology. Commission of Snow and Ice.] International Symposium on Antarctic Glaciological Exploration (ISAGE), Hanover, Nere Hampshire, U.S.A., 3-7 September 1968, p. 16-18. (Publication No. 86 [de l'Association Internationale d'Hydrologie Scientifique].)

Linkletter, G. O. 1973. Soluble particulates in ice from Site 2, Greenland. U.S. Cold Regions Research and Engineering Laboratory. Special Report i 88.

Linkletter, G. O., and Warburton, J. A. 1976. A note on the contribution of rime and surface hoar to the accumulation on the Ross Ice Shelf, Antarctica. Fournal of Glaciology, Vol. I 7, No. 76, p. 35I-54.

Lodge, J. P., jr. 1955. A study of sea salt particles over Puerto Rico. Journal of Meteorology, Vol. 12, No. 5, p. 493-99.

Murozumi, M., and others. I 69 . Chemical concentrations of pollutant lead aerosols, terrestrial dusts and sea salts in Greenland and Antarctic snow strata, by M. Murozumi, T. J. Chow and C. Patterson. Geochimica et Cosmochimica Acta, Vol. 33, No. 10, p. $1247-94$.

Ragone, S. E., and Finelli, R. V. 1972. Cationic analysis of the Byrd station, Antarctica ice core. U.S. Cold Regions Research and Engineering Laboratory. Special Report r8o.

Rossknecht, G. F., and others. 1973. The size distribution and inland penetration of sea salt particles, by G. F. Rossknecht, W. P. Elliott and F. L. Ramsey. Fournal of Applied Meteorology, Vol. 12, No. 5, p. 825-30.

Taljaard, J. J. 1972. Synoptic meteorology of the southern hemisphere. American Meteorological Society. Meteorological Monographs, Vol. 13, No. 35, p. 139-2 I 3 .

Toba, Y. Ig6I. Drop production by bursting of air bubbles on the sea surface (III). Study by use of a wind Hume. Memoirs of the College of Science, University of Kyoto, Ser. A, Vol. 29, No. 3, p. 313-44.

van Loon, $\mathrm{H}$, I972. Cloudiness and precipitation in the southern hemisphere. American Meteorological Society. Meteorological Monographs, Vol. 13, No. 35, p. IoI-1 I.

Warburton, J. A., and Linkletter, G. O. 1977 . Precipitation-forming mechanisms and the chemistry of precipitation on the Ross Ice Shelf, Antarctica. [Union Géodesique et Géphysique Internationale. Association Internationale des Sciences Hydrologiques. Commission des Neiges at Glaces.] Symposium. Isotopes et impuretés dans les neiges et glaces. Actes du colloque de Grenoble, aout/septembre r975, p. 88-94. (IAHS-AISH Publication No. 118. ) 